\title{
They Seek, but Do They Find? Investigating the Financial Information-Seeking Behavior of College Students
}

\author{
Alyson Vaaler, Lauren Reiter, and Ash E. Faulkner
}

\begin{abstract}
This paper reports the findings of a survey administered to a large academic university student population, assessing students' self-reported motivations, difficulties, and methods used in finding and using financial information. Results discussed include information types and sources students consult for financial information. The survey also explored students' perceptions of the relative ease of finding financial information and the degree of success students had in finding appropriate information. These results are relevant for librarians who support financial literacy through collection development or one-on-one patron support, or who are involved in developing financial literacy programs for libraries.
\end{abstract}

\section{Introduction}

Financial literacy is an important topic of interest in higher education. Ensuring that college students have an appropriate level of financial knowledge is an important aspect of national financial literacy efforts and of interest to librarians who support students in their academic and everyday challenges. However, there is a notable lack of research regarding how college students search for financial information and their successes and challenges in doing so. To analyze the financial information-seeking behavior of college students, the following research questions were explored:

1. What types of financial information are students looking for?

2. What prompts students to look for financial information?

3. What sources do students consult when they are looking for financial information?

4. What challenges do students have when navigating financial information?

While many studies have investigated trends in student academic information-seeking behavior, considerably less attention has been paid to student financial informationseeking behavior. The results of this research will explore the financial informationseeking behavior of college students and will examine implications for financial literacy support on campuses, as well as the role that libraries can and do play in supporting these students.

Alyson Vaaler is Assistant Professor in the University Libraries at Texas AEM University; email: asvaaler@library. tamu.edu. Lauren Reiter is Business Liaison Librarian at Pennsylvania State University; email: Imr29@psu.edu. Ash E Faulkner is Business Librarian at The Ohio State University Libraries; email: faulkner.172@osu.edu. (C2021 Alyson Vaaler, Lauren Reiter, and Ash E. Faulkner, Attribution-NonCommercial (https://creativecommons.org/ licenses/by-nc/4.0/) CC BY-NC. 


\section{Literature Review}

\section{Libraries and Financial Literacy}

With a reputation for offering free, trustworthy, and unbiased information resources, libraries naturally support information seeking in everyday life, and the scholarly literature provides ample evidence that this role extends to patrons' financial lives. A survey of public and academic librarians by the Reference \& User Services Association (RUSA) found that the majority of respondents were receiving personal finance reference questions in their libraries, with 60 percent reporting they received these questions at least occasionally. ${ }^{1}$

Support for financial information seeking is not limited to the reference desk; public and academic libraries are increasingly offering financial literacy programming as well. The same RUSA survey found that 36 percent of respondents reported their library offered financial literacy workshops, and 13 percent intended to do so in the near future. ${ }^{2}$ Smith and Eschenfelder found an even higher rate of participation among public libraries, with 82 percent offering financial literacy programming or services. ${ }^{3}$ Only 18 percent of respondents had offered financial literacy programming for more than six years, while 51 percent had offered programming for at least two years, suggesting fast-paced growth of these initiatives in the years following the 2008 recession.

Using the example set by public libraries and driven by concerns about student debt and college costs, more academic libraries began offering financial literacy programming, as evidenced by a surge in articles and case studies highlighting financial literacy programs in academic libraries from 2013 onward. ${ }^{4}$ According to one survey of large academic libraries, 45 percent offer some type of financial literacy programming. ${ }^{5}$ The body of literature on how to develop financial literacy programs in libraries is still growing with recent publications, such as ALA Editions' Rainy Day Ready: Financial Literacy Programs, suggesting a sustained interest in financial literacy programming among both public and academic libraries.

Library collections, with holdings ranging from textbooks to best sellers, are another important facet of library assistance with financial information seeking, but this topic has received limited attention in the literature compared to financial literacy programming. In one of the few studies in this area, Faulkner identified the themes and core concepts discussed in popular personal finance books, conveying the challenges faced by the financial information-seeking patron and the important role for librarians in helping patrons navigate the often contradictory guidance provided in these resources. ${ }^{6}$ In another study, Faulkner found that personal finance books and library financial literacy programming differ in the financial and educational goals they aim to achieve, as well as the audiences they serve, which librarians should bear in mind as they develop financial literacy collections and programming. ${ }^{7}$

While the literature demonstrates the capability and eagerness of libraries to support financial information seeking through reference, programming, and collections, these services are not without drawbacks. Librarians trying to help those seeking financial information must confront a myriad of challenges, including, potentially, the librarian's own lack of personal knowledge or training in personal finance. ${ }^{8}$ Other concerns include protecting patron privacy when handling sensitive information; liability issues for the library should they cross the line from offering financial information to financial advice; and committing time, resources, and space to financial literacy amid competing priorities. $^{9}$ 


\section{Everyday Life Information-Seeking Behavior}

In an academic context, studies show that students desire quick access to resources they need. A study conducted by Connaway, Dickey, and Radford saw that convenience factors such as access, ease of use, and time largely guided how students chose resources; sometimes students even willingly sacrificed the content of a source in favor of these other factors. ${ }^{10}$ Similarly, Komissarov and Murray found that students placed an emphasis on full-text availability over other source attributes such as being recent or peer reviewed..$^{11}$ This emphasis on quick, easy access to resources appears to hold true across distinct student populations. ${ }^{12}$

Outside of academia, studies have investigated information seeking in an everyday context and have found that people rely on their own experience, informal information sources, and personal networks to obtain information for daily activities. A model presented by Savolainen formalized ways to research the information-seeking processes in daily life and led to more studies being conducted on various everyday life information-seeking (ELIS) scenarios. ${ }^{13}$ Studies done on information seeking in various occupations such as farming, engineering, and nursing have all found that, regardless of the diverse information needs for each occupation, information is mainly obtained through informal information sources such as personal networks. ${ }^{14}$

\section{Financial Information-Seeking Behavior}

A portion of the literature that analyzes everyday life information-seeking behavior focuses specifically on financial information-seeking behavior. These studies typically focus on the sources people use to address a particular financial event and why they select these sources. While very few studies were located that explored the unique financial information-seeking behavior of college students, many studies have focused on informationsearch behavior related to retirement, investing, and consumer purchasing decisions. Retirement is an event that is frequently studied in financial information-seeking behavior literature. A study by Johansen found a person's social environment and the availability of retirement information positively affected enrollment in an employer-based pension plan. ${ }^{15}$ Another study examined the sources that women used to make decisions about saving for retirement and concluded that younger women who relied more on information from friends/ relatives saved less than older women who consulted financial professionals. ${ }^{16}$ Another financial event that is also addressed in the literature is investing and related personal interactions. In some instances, investors were observed gathering information from a variety of sources, including informal networks online. ${ }^{17}$

Consumer purchasing decisions for various products are also widely studied, often drawing conclusions based on demographic groupings of consumers or investigating the specific information sources they used. Fan and Chatterjee investigated comparison shopping for credit cards and mortgages and found that older individuals were more likely to compare credit card and mortgage loan offerings than underserved groups. ${ }^{18}$ Savolainen interviewed homebuyers on the most important criteria for sources used during the home-buying process and concluded that the timeliness of information was particularly important based on the quickly changing market. ${ }^{19}$ Another study investigated both the individual consumer and their shopping environment to analyze the effect that browsing had on their final purchase. ${ }^{20}$ Overall, studies showed that, similar to other everyday life-seeking information behavior, the emphasis on quick, easy-to-access information held true regardless of the financial product or behavior being studied. 


\section{College Students and Financial Literacy}

Studies exploring the financial literacy of college students fall mainly into two categories: measuring the financial literacy of various student populations and studying the impact of financial literacy instruction on student behavior. Almost all of these studies measure two distinct levels of financial literacy: subjective (students' perceptions of their own literacy) and objective (measures of financial literacy assessed through standard financial wellness questions). It is also common for researchers to explore students' financial literacy in regard to particular topics: credit, saving, insurance, investment, and the like.

Overall average levels of objective financial literacy among students have ranged widely in research, but levels are generally low, with correct response rates to objective measurement tools of: 53 percent, 40 percent, and, at best, 69 percent..$^{21}$ In fact, Lusardi and Wallace asserted that youth are often the population subgroup with the lowest level of financial literacy, in the United States and in other countries. ${ }^{22}$ Financial literacy levels appear to vary on the basis of gender, race and ethnicity, foreign or domestic student status, student majors, and parent educational backgrounds.

The demographics most studied in relation to financial literacy have been gender, race, and ethnicity. In general, male students score higher on financial literacy assessments than their female counterparts, and female students are also more likely to indicate they "don't know" the answers to financial literacy questions, suggesting they are also less confident in their knowledge. ${ }^{23}$ It has also been found that, on the whole, minority students score lower on financial literacy assessments than their white counterparts. ${ }^{24}$

Many studies have also related financial literacy to students' domestic status, majors, and parents' financial background. Business majors are generally more knowledgeable on financial literacy topics than nonbusiness majors. ${ }^{25}$ As a group, domestic students earn higher scores on financial literacy assessments than foreign students. ${ }^{26}$ Last, some studies have found that students with more highly educated parents score higher on financial literacy assessments than their counterparts, but others have found that parental influence is based more on modeling positive behaviors and may impact students' behaviors, but not their overall levels of knowledge. ${ }^{27}$ Of the specific knowledge areas explored, researchers have found students most knowledgeable about financial literacy topics related to credit and least knowledgeable about taxes. ${ }^{28}$ That said, LaBorde, Mottner, and Whalley reported that only 15 percent of their respondents knew the factors determining credit-worthiness, though most were borrowing money. ${ }^{29}$

Very few studies were located that explored the financial information-seeking behaviors of undergraduate students. In 2011, Head and Eisenberg explored the research habits of college students, but the exploration of financial information-seeking behaviors was limited to a brief discussion of the use of search engines for research related to upcoming purchases. ${ }^{30}$ A study by Huang, Lassu, and Chan used a survey study limited to business students (whom research suggests may have markedly different levels of financial literacy) and focused more specifically on perceptions of source value as opposed to a broader exploration of students' search triggers and perceptions of the information-seeking process as a whole. ${ }^{31}$ One survey of particular note to this research is the Study on Collegiate Financial Wellness (SCFW), conducted at The Ohio State University. In 2017 the survey was administered on 90 college and university campuses with 28,539 responses from undergraduate students, exploring financial attitudes, practices, and knowledge. However, while this study explored common concerns 
like student loans, credit cards, general financial behaviors and even financial knowledge, education, and self-efficacy, the survey did not explicitly examine financial information-seeking behaviors. ${ }^{32}$

\section{Financial Literacy Instruction}

There is a particularly solid base of literature devoted to the study of financial literacy instruction interventions with undergraduate students, though one of the central debates of this literature regards the efficacy of these interventions in impacting either long-term financial literacy levels, or financial decision-making. There are many studies that find conflicting evidence regarding the efficacy of financial literacy instruction, and some authors, like Willis, argue against financial literacy education initiatives, asserting that these initiatives cannot cover the expanse of knowledge needed and may actually do more harm than good by making participants overconfident. ${ }^{33}$ Most authors report mixed utility for financial education initiatives, especially if interventions happen a great deal of time before students would enact desired financial behaviors. ${ }^{34}$ Generally, studies find that financial literacy courses have a positive effect on financial behaviors, but there is disagreement about how these effects might differ on short-term financial behaviors versus long-term financial behaviors. ${ }^{35}$

Two meta-analyses have examined financial literacy education and downstream financial behaviors. Fernandes, Lynch, and Netemeyer concluded after an analysis of 168 papers that interventions to improve financial literacy explain only 0.1 percent of the variance in financial behaviors studied. ${ }^{36}$ Miller, Reichenstein, and Zia reviewed 188 financial education interventions and determined that, while 140 indicated financial education can improve financial outcomes, most of those studies employed nonrigorous empirical methods and 40 studies concluded either no impact or only a modest impact from intervention. ${ }^{37}$

There has been significant research done into both information-seeking behaviors and financial literacy. However, there have not been any studies that specifically examine the financial information-seeking behavior of college students. Our study will address this gap by analyzing the self-reported motivations, difficulties, and methods college students use in finding and using financial information.

\section{Methodology}

The survey instrument (see appendix) and protocol were reviewed by the Institutional Review Boards of Texas A\&M University, The Ohio State University, and Penn State University and were determined to be exempt before distribution. The authors designed the 14-question survey instrument using Qualtrics based on answers to an initial pilot survey distributed to a test sample of students. In October 2019, the authors sent out the survey via a Texas A\&M University student listserv of 53,725 subscribers. Respondents were given the option to enter a drawing for one of $20 \$ 50$ Amazon gift cards upon completion of the survey. The survey was open for four weeks and received 1,040 responses. Two respondents disagreed with the opening IRB Statement and 105 respondents did not complete the entire survey, resulting in 933 complete survey responses analyzed. At a confidence level of 95 percent and a margin of error of 4 percent, the authors considered the resulting dataset acceptable to use in an exploratory analysis of the research questions.

Of the 929 students who responded to the demographic questions, more females than males answered the survey. The three largest ethnic groups responding were White $(45 \%, \mathrm{n}=$ 

253), and Hispanic or Latino (20\%, $n$ $=186$ ). Half of the respondents were either Freshman $(24 \%, n=229)$ or Graduate Students $(26 \%, \mathrm{n}=238)$, which is reflected in the age range of respondents with just over half being $18-20$ years old $(55 \%, n=515)$ and a quarter of the respondents falling into the $21-23$ age range $(23 \%, n$ $=222)$. The majority of respondents $(67 \%, \mathrm{n}=627)$ had not taken a formal financial literacy class, and an equal number of students identified that they were not first-generation students $(67 \%, n=630)$ (see table 1$)$. representative of Texas A\&M University's student body, which is 53 percent male and 46 percent female, with 56 percent of students reporting non-first-generation student status. White students represent 55 percent of the student population, Hispanic students represent 22 percent, Asian students represent 8 percent, and Black or African American students represent 3 percent of the total student body. ${ }^{38}$ The survey pool included a surprisingly large response rate from the Asian/Pacific Islander ethnic group, but the survey also did not ask students to identify if they were international students, a group that represents 8 percent of Texas A\&M University's student population. The survey's large response rate from the Asian/Pacific Islander group could be partially attributed to international student responses.
419), Asian/Pacific Islander $(27 \%, \mathrm{n}=$

These demographics are fairly

\begin{tabular}{|c|c|c|}
\hline \multicolumn{3}{|c|}{$\begin{array}{c}\text { TABLE } 1 \\
\text { Demographics of Survey Participants }\end{array}$} \\
\hline Demographic Characteristic & $\mathbf{n}$ & Percentage \\
\hline \multicolumn{3}{|l|}{ Sex } \\
\hline Female & 627 & $67 \%$ \\
\hline Male & 288 & $31 \%$ \\
\hline $\begin{array}{l}\text { Prefer to self-describe, not to say, or } \\
\text { did not disclose }\end{array}$ & 14 & $2 \%$ \\
\hline \multicolumn{3}{|l|}{ Race/Ethnicity } \\
\hline White & 419 & $45 \%$ \\
\hline Asian/Pacific Islander & 253 & $27 \%$ \\
\hline Hispanic or Latino & 186 & $20 \%$ \\
\hline Black or African American & 31 & $3 \%$ \\
\hline Native American or American Indian & 6 & $1 \%$ \\
\hline Other or prefer not to answer & 34 & $4 \%$ \\
\hline \multicolumn{3}{|l|}{ Class Standing } \\
\hline Freshman & 229 & $24 \%$ \\
\hline Sophomore & 148 & $16 \%$ \\
\hline Junior & 164 & $18 \%$ \\
\hline Senior & 141 & $15 \%$ \\
\hline Graduate student & 238 & $26 \%$ \\
\hline Other & 9 & $1 \%$ \\
\hline \multicolumn{3}{|l|}{ Age } \\
\hline $18-20$ & 515 & $55 \%$ \\
\hline $21-23$ & 222 & $23 \%$ \\
\hline $24-26$ & 98 & $11 \%$ \\
\hline $27-29$ & 42 & $5 \%$ \\
\hline 30 or older & 52 & $6 \%$ \\
\hline \multicolumn{3}{|l|}{ Financial Literacy Training } \\
\hline Yes & 306 & $33 \%$ \\
\hline No & 627 & $67 \%$ \\
\hline \multicolumn{3}{|l|}{ First Generation } \\
\hline Yes & 299 & $32 \%$ \\
\hline No & 630 & $67 \%$ \\
\hline
\end{tabular}

There are limitations to this study, namely that the survey tool was deployed on one university campus. In addition, students had to opt in to complete the survey; therefore, our sample may be skewed to students with an interest in, or existing knowledge of, financial literacy. This is an exploratory study and is limited by the potential bias of self-reported answers. Generalizing these results, especially beyond the scope of US higher education students, is 
not possible. Exploring the financial information-seeking behaviors of US-based students in other types of higher education institutions, higher education students in other locations in the world, and through methods less impacted by selection bias may all be prime areas for future research.

\section{Results}

1. What types of financial information are students looking for?

In the first survey question, respondents were asked to indicate what types of financial information they had searched for in the last 12 months by checking all the options that applied. Many of the response options were widely chosen. "Cost of a purchase" $(74 \%, \mathrm{n}=$ 687) was the most popular response, followed very closely by "Salary for future job" (73\%, n $=685)$ and "Financial aid/student loans" (73\%, $\mathrm{n}=681$ ). In all, investments, auto loans, and mortgages were the three areas students were least likely to have researched in the past 12 months (see table 2).

Notably, the interest in investments did not seem strongly related to class standing-among those who checked this option, 22 percent indicated their class standing as

\begin{tabular}{|l|c|c|}
\hline \multicolumn{3}{|c|}{ TABLE 2} \\
\hline $\begin{array}{l}\text { Types of Financial Information } \\
\text { Information }\end{array}$ & $\mathbf{n}$ & Percentage \\
\hline Cost of purchase & 687 & $74 \%$ \\
\hline Salary for future job & 685 & $73 \%$ \\
\hline Financial aid/student loans & 681 & $73 \%$ \\
\hline Credit cards & 566 & $61 \%$ \\
\hline Choosing a bank & 484 & $52 \%$ \\
\hline Budgets & 484 & $52 \%$ \\
\hline Taxes & 406 & $44 \%$ \\
\hline Credit scores & 398 & $43 \%$ \\
\hline Investments & 256 & $27 \%$ \\
\hline Auto loans/auto leasing & 136 & $15 \%$ \\
\hline Home mortgages & 48 & $5 \%$ \\
\hline
\end{tabular}
freshman, 29 percent as graduate students, and 20 percent as juniors. However, of those who indicated they had investigated auto loans or leasing, 38 percent were graduate students; and, of those who had researched home mortgages, 55 percent were graduate students.

Of the 29 people who responded "Other," 28 gave text responses. The most popular categories in these text responses were scholarship information, medical bills, and issues related to car/home costs, including one respondent who specified they had researched a mortgage refinance. Other unique responses included: "Energy savings," "Bitcoin," and "Retirement." These indicate that there are at least some students interested in a wide range of financial topics, which may increase their need for financial information literacy to find more niche resources. One respondent indicated that they had not searched for any financial information in the past 12 months, stating, "I don't understand finance at all." For students such as this, financial information literacy will be equally important to help them navigate any initial searches. This might also indicate a need on campus for some broad, background resources.

\section{What prompts students to look for financial information?}

For the rest of the survey, students were asked to think of a singular time they searched for financial information and base their responses on that experience. To explore the motivations behind their searches, students were asked to fill in a free-text response answer to the question "What prompted you to search for the financial information?" (See question 6.) In total, 838 of the 933 survey respondents answered this question. Most were single responses, but many respondents also identified multiple prompts for information. There were many responses 
that correlated closely with the types of financial information students had looked for-information on auto loans, budgeting, credit cards, financial aid and student loans, and salaries for future jobs - but the free-text responses also allowed for more nuanced themes to emerge.

The most dominant of these themes was need (for more money and/or more financial knowledge to obtain more money) and a claim of, or fear of, "being poor." The word "need" appeared in 201 responses, 24 percent of all respondents for this question. In coding the text responses to this question, the broader theme of need and/or fear of the consequences of poor financial management was particularly emphasized in 193 responses. In their responses, two separate respondents answered, simply, "fear." Others expanded a bit to explain, "I do not want to live paycheck to paycheck," or "I don't want to be broke and homeless in the future." It seems clear that there is a very real anxiety among many of the respondents regarding their current and/or future financial standing.

In fact, the next most dominant theme was a persistent focus on the future, some of this relating back to fear of future financial difficulties, but some of it was more generally an acknowledgment of the financial status changes and responsibilities that come with adulthood. In answering this question, 144 responses included the word "future." Relating back to fear of one's financial future, one respondent explained that what prompted them to search for financial information was: "Preparation for my well-being in the future, by making sure I have enough finances to start off my life with food, clothing, a reliable home, and a reliable source of transportation." Another said, "I need to be knowledgeable about my future and the expenses that will incur. I do not want to go into it blindly, so I would like to start budgeting for it now." A third respondent related his/her current financial learning to early preparation for future financial stability: "I want to make sure I have a full understanding of things I may need in the coming years as I want to be prepared to have the best financial stability possible after I graduate."

It was very common for survey respondents to indicate that, as part of their consideration for the future, they were looking into salary information, either to inform specific company and/or job location choices, or even as a means to start contemplating various career options on a whole. In coded responses, 49 stood out as highlighting this subset future concern. Most of these responses focused on general thoughts regarding a particular future job (considering job options, comparing salary offers, and so on), but there was also a set of respondents who more clearly emphasized that they were making decisions regarding their overall career paths, or even college majors, based on earnings potential.

One student explained that what prompted them to search for financial knowledge was this: "I am also in the job market and wanted to see the salaries of different companies in different areas to understand the value of my degree and skills." Another expanded that they were "trying to compare the salaries of future professions to ensure I would be well off in the future." One note to make about these comments is that, while salary comparisons are an important part of overall career considerations, there should be other considerations as well. Another student reported, "I was looking for future job salaries to decide a career path." While future job salaries should no doubt play some role in that decision, awareness should be brought to the fact that it may be playing an exclusive role for some students.

The theme of credit and obtaining, or paying off, loans was also dominant. Unsurprisingly, a large number of these wider credit and loan issues were related to paying for schooling. It makes sense that student respondents to a survey administered on a university campus might 
be preoccupied with costs related to schooling. What might surprise some is how strong this emphasis was. Of total responses, 97 responses focused broadly on credit or loan concerns, but 208 responses were focused specifically on school cost concerns; that's more than two times as many responses focusing on school costs rather than broader credit and loan considerations. Some respondents simply emphasized a general need to build credit: "I know building credit is something I need to do sooner rather than later." But in far greater numbers, respondents emphasized that the greatest driver for their need of credit (or financial assets) was schooling costs: "I need money because college is super expensive," one respondent explained. Another related schooling costs back to the theme of fear: "I look at how much money I pay each semester and I panic and look for scholarships."

One interesting observation from these text responses was that a period of transition often played a role in students' decision to explore financial information. A lot of students reported being in a transition period wherein they faced a more pressing need for financial information. These students were either transitioning into college and independent living, into graduate school, or into a career. There was also a significant minority of students transitioning geographically -US students considering study-abroad opportunities or international students studying at the survey institution. Overall, a period of transition was highlighted in 112 responses.

One student conveyed that what prompted them to search for financial information was "the realization that I am an adult." Another summarized still more succinctly that the prompt was "Adulting." While there is a heightened sense of anxiety attached to the transition to financial independence, it is encouraging that this is an area of need that students are striving to address. Perhaps one of the encouraging conclusions that can be drawn from these responses is a seemingly widespread understanding that financial literacy, and financial responsibility, is a requisite component of adulthood.

Less encouraging is the indication in a number of free-text responses that financial literacy is an area that many students feel they need to address individually. Respondents mentioned that they had not and/or were not receiving financial literacy education anywhere beyond individual pursuit. In fact, only a third of survey respondents indicated that they had received some formal financial literacy training at some point in their lives (see question 9). One respondent complained, "Things like taxes and salaries aren't taught unless you ask around or Google it yourself." Another lamented, "I want to understand what's going on with myself financially, and they don't teach you it in school, so I had to find it out myself." While individual pursuit is infinitely superior to sustained ignorance, there are undeniable challenges to a lack of concrete guidance. One respondent expanded on their individual pursuit of financial knowledge: "I haven't searched for concrete answers, just ideas because I don't exactly know what to look for or what I need. If I know I want to adjust my budget, I will search the web for how other people do it, hoping I can find something they do that is helpful." Only two respondents pointed out that there were sources for financial literacy guidance on their campus. One indicated, "I was invited to a financial literacy workshop," and this sparked their pursuit of additional knowledge. The other indicated, "I visited the Money Education Center and [they] gave me more information about what I should look at financially and some smart decisions I can make."

Perhaps on a final encouraging note, general curiosity also played a role in respondents' prompts to look up financial information. Seventeen responses included the word "curious," 
and a total of 78 coded responses highlighted a general curiosity or interest driving the decision to research a financial topic. The possible downside to this general curiosity might be a lack of action associated with gained financial knowledge. One respondent in this category stated, "I was curious about it. I didn't actually do anything with the information." But overall, it's a positive sign that there are students personally interested in such an important piece of literacy. One surprisingly insightful student summarized, "I knew how I managed money now would affect how I managed money later and how much money I had," and another summarized still more broadly, "As a human being, money is important. It would be foolish to not try and understand personal finances."

3. What sources do students consult when they are looking for financial information? To determine what sources students consulted for financial information, survey respondents were asked to think of a time they searched for financial information and identify a source or sources they used during their search (see question 2). Nearly all respondents indicated that they used the internet for their search $(94 \%, \mathrm{n}=879)$. Family $(72 \%$, $\mathrm{n}=673)$ and Friends $(53 \%, \mathrm{n}=491)$ were the next two selected sources, significantly used over other sources of financial information.

The use of family and friends as a source differed depending on the age of the student.

\begin{tabular}{|l|c|c|}
\hline \multicolumn{3}{|c|}{ TABLE 3} \\
Sources of Financial Information \\
\hline Source & n & Percentage \\
\hline Internet & 879 & $94 \%$ \\
\hline Family & 673 & $72 \%$ \\
\hline Friends & 491 & $53 \%$ \\
\hline $\begin{array}{l}\text { Financial Professional or } \\
\text { Financial Center on Campus }\end{array}$ & 210 & $23 \%$ \\
\hline Apps & 191 & $21 \%$ \\
\hline Social Media & 172 & $18 \%$ \\
\hline Other & 26 & $3 \%$ \\
\hline
\end{tabular}
Younger students ages 18-23 ( $\mathrm{n}=737)$ were more likely to consult family members $(78 \%, n=578)$ over friends $(52 \%, n=383)$. Students ages 24 and older $(n=192)$ consulted family members less often $(48 \%, n=92)$, but they still relied on friends as a source for financial information $(55 \%, n=106)$. Besides this difference, other demographic breakouts of student responses revealed little variation in the sources consulted.

Interestingly, older students were no more likely to seek out a financial professional or financial center on campus $(22 \%, n=42)$ than younger students $(23 \%, n=168)$. However, students who indicated that they had formal financial literacy training $(32 \%, n=299)$ did report a higher usage of a financial professional or financial center on campus $(29 \%, n=88)$. This usage was higher than the students who had no formal financial literacy training $(66 \%, \mathrm{n}=$ $610)$ and reported using a financial professional or financial center on campus $(19 \%, n=116)$. No other population of students (gender, ethnicity, age, or any other factor) reported using a financial professional or financial center on

\section{TABLE 4}

\section{Criteria Most Important in a Source}

\begin{tabular}{|l|c|c|}
\hline Criteria & $\mathbf{n}$ & Percentage \\
\hline Trustworthiness of a source & 850 & $91 \%$ \\
\hline Expertise of a source & 677 & $73 \%$ \\
\hline Purpose of a source & 530 & $57 \%$ \\
\hline Currency of information & 456 & $49 \%$ \\
\hline Other & 26 & $3 \%$ \\
\hline
\end{tabular}
campus more than others.

Besides the type of source used, the survey also asked what criteria students found most important in a source when they were looking for financial information and allowed them to select all the criteria that applied (see question 7). The majority of students selected trustworthiness of a source $(91 \%, n=850)$ over other options provided 
(see table 4). Other important criteria written in by students included the ease of access and readability, how unbiased the source was, and if the information was targeted specifically to students.

\section{What challenges do students have when navigating financial information?}

Several survey questions aimed to identify the challenges experienced by students seeking financial information, including the overall level of difficulty, the duration of the search, and the success of that search. These survey questions (see questions 3, 4, and 5) were cross-tabulated with demographic data, but no significant relationships emerged.

To gauge the difficulty of navigating financial information, survey respondents were asked to rate how easy or difficult it was to find the financial information they sought (see question 3). In total, 932 students responded to this question, and the results show that most students perceive it to be easy to find financial information, with $44 \%$ rating their search as "Easy" $(38 \%, n=357)$ or "Very easy" $(6 \%, n=56)$. A significant proportion of students rated their search as "Neither easy nor difficult" $(37 \%, \mathrm{n}=346)$ and a lower number found it "Difficult" $(18 \%, n=166)$ or "Very difficult" $(1 \%, n=7)$ to find what they needed.

Certain topics may also be more or less time-consuming to investigate, which may also affect the perception of difficulty. Of the 932 students who answered the survey question that asked how long they searched for the financial information they needed (see question 4 ), most students responded that they searched for 10-30 minutes (39\%, n = 364). The next most popular response was 30 minutes to 1 hour $(30 \%, n=276)$, followed by $1-3$ hours $(13 \%$, $n=125)$ and less than 10 minutes $(13 \%, n=117)$. Only $3 \%(n=50)$ spent more than 3 hours researching financial information.

While most reported spending a moderate amount of time researching financial information (10 minutes to 1 hour), those who spent more time researching financing information (1 hour or more) were more likely to rate the experience higher in difficulty (see table 5). Students searching for information for a longer time may be investigating a complex or unfamiliar topic, encountering obstacles, or

\begin{tabular}{|l|c|c|}
\hline \multicolumn{3}{|c|}{ TABLE 5 } \\
Time vs. Ease \\
\hline & 0-1 Hours & $\mathbf{1 +}$ Hours \\
\hline Easy or very easy & $50 \%$ & $19 \%$ \\
\hline Neither easy nor difficult & $39 \%$ & $30 \%$ \\
\hline Difficult or very difficult & $11 \%$ & $50 \%$ \\
\hline
\end{tabular}
seeking more comprehensive answers to their financial questions.

Even if they spent a great deal of time on the search or found the exercise to be easy, not all respondents were able to find the information they needed. Of the 932 responses, 57\% $(n=$ $530)$ indicated that they found the information they needed, $40 \%(n=374)$ responded that their outcome somewhat met their need, and $3 \%(n=$ 28) said that they did not find what they needed (see question 5).

The ease or difficulty of the search corresponded to the success or failure of the search. Students who were able to find what they needed were more likely to rate their search as "Easy" or "Very easy" than their peers who reported that they did not find what they needed (see table 6).

\begin{tabular}{|l|c|c|}
\hline \multicolumn{3}{|c|}{ TABLE 6} \\
Ease vs. Success of Finding Information \\
\hline & \multicolumn{2}{|c|}{$\begin{array}{c}\text { Did they find } \\
\text { what they need? }\end{array}$} \\
\hline & Yes & No \\
\hline Easy or very easy & $63 \%$ & $11 \%$ \\
\hline Neither easy nor difficult & $29 \%$ & $36 \%$ \\
\hline Difficult or very difficult & $8 \%$ & $53 \%$ \\
\hline
\end{tabular}


Students who did not find what they were searching for were more likely to rate their search as "Difficult" or "Very difficult." These results suggest that the outcome of the search has a notable effect on the perceived difficulty. For students seeking financial information, it is the destination rather than the journey.

Still, other students did not arrive at a definitive conclusion to their financial information seeking. Of the total number of students, 40 percent completed their search with an outcome that only somewhat met their needs, suggesting that they may have settled for "good enough" information rather than identifying optimal financial information. This supports previous research findings that college students searching for information will often use information out of convenience, even if it is not the best source of information to use or doesn't result in a complete answer to a question. ${ }^{39}$

Question 8 addressed challenges students may face when researching financial information. The majority agreed that a challenge when searching for financial information is knowing where to look (see table 7). Notably, those who were able to find what they were looking for and those who were not (see question 5) felt differently about this particular challenge. Of those who were able to find what they need, only 45 percent agreed with this statement. Of those who did not find what they need, 57 percent agreed with this statement. Of those who indicated that they somewhat found what they needed, 76 percent agreed that not knowing where to look was a challenge. If students did not find the information they sought or felt it was incomplete, they were more inclined to point to not knowing where to look as a challenge.

\begin{tabular}{|l|l|l|l|l|l|}
\hline \multicolumn{7}{|c|}{ CABLE 7 } \\
\hline & $\begin{array}{l}\text { I don't } \\
\text { know } \\
\text { where to } \\
\text { look }\end{array}$ & $\begin{array}{l}\text { I would } \\
\text { rather ask } \\
\text { someone for } \\
\text { help }\end{array}$ & $\begin{array}{l}\text { I find } \\
\text { information } \\
\text { that contradicts } \\
\text { itself }\end{array}$ & $\begin{array}{l}\text { There is } \\
\text { too much } \\
\text { information }\end{array}$ & $\begin{array}{l}\text { I don't } \\
\text { trust the } \\
\text { information } \\
\text { I find }\end{array}$ \\
\hline Agree or somewhat agree & $58 \%$ & $52 \%$ & $52 \%$ & $43 \%$ & $33 \%$ \\
\hline $\begin{array}{l}\text { Neither agree nor } \\
\text { disagree }\end{array}$ & $15 \%$ & $20 \%$ & $16 \%$ & $22 \%$ & $33 \%$ \\
\hline $\begin{array}{l}\text { Disagree or somewhat } \\
\text { disagree }\end{array}$ & $27 \%$ & $29 \%$ & $23 \%$ & $35 \%$ & $34 \%$ \\
\hline
\end{tabular}

The next challenge most students agreed with was this one: "I would rather ask someone for help than look for information on my own" (see table 7). The high percentage that agrees with enlisting the help of others rather than searching on their own corresponds with the finding in survey question 2 that the majority of students turn to family and friends as sources for financial information.

Students were also asked whether or not they agreed that "I find information that contradicts itself." While the majority of students agreed with this statement, nearly a quarter disagreed that the information they were finding contradicted itself. In response to the statement "I don't trust the information I find," students were equally split between trusting the information, being neutral, and not trusting the information they were finding. The varying degrees of trust in information may indicate that, to the students' perceptions, the quality of the information they were encountering varied. This also supports student responses to question 
8 regarding finding contradictory information. All of these responses relate to earlier student responses that the most popular criteria for evaluating information was the trustworthiness of the source.

A lower-than-expected number of students $(43 \%, \mathrm{n}=398)$ were in agreement that "There is too much information." In contrast to the concerns within the library profession that patrons are overwhelmed in a vast sea of information, these findings show that this issue is of less concern to students, at least in regard to financial information. Students are not feeling overwhelmed by financial information, despite there truly being a vast amount of it available. This may suggest a need to increase students' awareness of financial support available.

\section{Discussion}

Results of the survey gave the authors further insight into the financial information-seeking behavior of college students. Unsurprisingly, students were most often searching for the cost of a purchase, salary for a future job, and information pertaining to financial aid or student loans. However, these financial literacy needs varied slightly from those financial topics discussed in library literature. Reiter and Ford surveyed librarians on what topics were most important to their students and found that personal finance basics, student loans, and budgeting were perceived to be the most important financial literacy topics for students. ${ }^{40}$ While there are overlaps, the differences may be due to varying local needs, diverse users, or differences in understanding users. However, the possible disconnect between perceived student financial information needs and what students are actually searching for is an important point to consider. Reiter and Ford's survey also revealed that, when it comes to financial literacy, librarians are often limited by time and resources. ${ }^{41}$ Knowing this, it might help librarians to be aware of exactly what financial topics students are looking for in their local context to develop targeted instruction, collect materials, and curate content on the most critical topics.

One topic that received particular emphasis throughout the survey was salary information. The authors were surprised at the number of responses from students that highlighted a need for salary information and the number of students who linked this with an acute sense of fear and anxiety about the future. It may be worth noting that most of the survey respondents are classified as belonging to Generation $Z$, a generation that researchers theorize are more fiscally conservative and fearful about the future due to childhood experiences of the Great Recession. ${ }^{42}$ This could explain the general fear and anxiety that was highlighted in the survey responses and the emphasis on salary information. Librarians could use this information to understand the lived experiences of students and attempt to allay fears about career salaries. However, librarians could also be prepared to explore other career-related information that might be of interest to students such as salary negotiation strategies, company values, or Environmental, Social, and Corporate Governance ratings. These parallel topics might catch the attention of students interested in salary information and may be topics that students haven't previously thought about investigating.

An encouraging response to the survey involved students' realization of the importance of financial literacy. Many students articulated they needed to know more about financial literacy topics because these topics would be important to them in their transition to adulthood. However, many students responded that they were mostly attempting to learn about these topics on their own, either through the internet or by asking friends and family. Even though responses to the survey indicated that students perceive that they are finding informa- 
tion fairly easily, the survey didn't ask about the specific sources they are using or anything about how they evaluated the expertise or trustworthiness of the sources. Future research could explore the specific resources that students are using and the quality and effectiveness of these sources.

As expected, students are experiencing challenges with finding financial information. A large percentage of students indicated that they didn't know where to look for information and that the information they found was contradictory. Students also commented that they highly valued information that was designed specifically for college students. Libraries can use this information to focus on curating resources that are student focused and to plan instruction and workshops with this student-centered focus in mind.

A surprisingly high number of students responded that they would rather ask someone for help than try to search for information on their own. The results of the survey showed that, besides the internet, students seek out information from people, notably family and friends. Unlike other types of sensitive information, financial information seeking is generally a collaborative effort as opposed to a solo endeavor. For libraries, it is important to understand that library collections and programs exist within a broader context of resources, regardless of their authority.

\section{Conclusion}

While more research is needed to better understand the financial information-seeking behavior of college students, this exploratory study is one of few to address the topic and provides insights for those interested in aligning library financial literacy efforts and library services in general with student perspectives. Results confirm that college students are interested in their financial well-being and in finding trustworthy information to guide the financial decisions that impact their present and future. While they reported being able to find financial information with relative ease, not all were successful; and the study reveals how both anxiety and striving for a stronger financial future drove them to seek out financial information. Unsurprisingly, given previous research, as well as their sensitivity to the subject, college students consult familiar sources for financial information, namely the internet, family, and friends.

While libraries or librarians were not identified as part of the personal network that students turn to for financial information, libraries do have a reputation as trusted information providers, and trustworthiness ranks highly in students' criteria for evaluating a financial information source. Librarians can explore building on their trusted role in students' academic lives to include support for everyday life information seeking. As the study found, students lack awareness of the numerous options available for financial education and may not recognize the library as a potential node in their financial information network. With the greater understanding of financial information-seeking behavior provided by this study, libraries can better anticipate and empathize with the financial questions and fearful feelings students may have, know what sources they are likely to have consulted, and ultimately develop programs, collections, and services that align with the knowledge and information that college students most value and need for their financial lives now and in the future. 


\section{Appendix A}

Q1 What types of financial information have you looked for? Check all that apply.

\begin{tabular}{|l|c|}
\hline & $\begin{array}{l}\text { I have looked for this } \\
\text { information... }\end{array}$ \\
\hline & In the last 12 months (1) \\
\hline Auto Loans/Auto Leasing (1) & $\square$ \\
\hline Budgets (2) & $\square$ \\
\hline Choosing a Bank (savings/checking accounts) (3) & $\square$ \\
\hline Cost of a purchase (4) & $\square$ \\
\hline Credit Cards (5) & $\square$ \\
\hline Credit Scores (6) & $\square$ \\
\hline Financial Aid/Student Loans (7) & $\square$ \\
\hline Home Mortgages (8) & $\square$ \\
\hline Investments (stocks, bonds, mutual funds, etc.) (9) & $\square$ \\
\hline Salary for future job (10) & $\square$ \\
\hline Taxes (11) & $\square$ \\
\hline Other (12) & $\square$ \\
\hline
\end{tabular}

Q2 Thinking of a time you searched for financial information, which source(s) did you use?

Family-word of mouth (1)

․ Friend - word of mouth (2)

$\square$ Browsing the Internet (Google, Wikipedia, Blogs, etc.) (3)

$\square$ Social Media (4)

Financial Professional or Financial Center on Campus (5)

$\square$ Apps (Mint, YNAB, Stash, etc.) (7)

$\square$ Other (6)

Q3 How easy or difficult was it to find the financial information you were looking for?

口 Very Easy (0)

$\square$ Easy (1)

Neither Easy or Difficult (2)

$\square$ Difficult (3)

口 Very Difficult (11)

Q4 How long did it take you to find the information you needed?

$\square \quad$ Less than 10 Minutes (1)

10-30 Minutes (2)

30 Minutes-1 Hour (3)

ㅁ 1-3 Hours (4)

$3+$ Hours (5)

Q5 Were you able to find the information you needed?

$\square \quad$ Yes (1) 
$\square \quad$ No (2)

$\square$ Somewhat (3)

Q6 What prompted you to search for the financial information?

Q7 When looking for financial information, what criteria is important to you?

$\square$ Currency of information (1)

$\square \quad$ Trustworthiness of a source (2)

$\square \quad$ Expertise of a source (3)

$\square \quad$ Purpose of a source (education, selling something, etc.) (5)

$\square \quad$ Other criteria (please describe) (6)

Q8 How strongly do you agree or disagree with the following statements about searching for financial information?

\begin{tabular}{|l|l|l|l|l|l|}
\hline & $\begin{array}{c}\text { Disagree } \\
(1)\end{array}$ & $\begin{array}{c}\text { Somewhat } \\
\text { Disagree (2) }\end{array}$ & $\begin{array}{l}\text { Neither Agree } \\
\text { or Disagree (3) }\end{array}$ & $\begin{array}{c}\text { Somewhat } \\
\text { Agree (4) }\end{array}$ & Agree (5) \\
\hline There is too much information (1) & & & & & \\
\hline I don't know where to look (2) & & & & & \\
\hline $\begin{array}{l}\text { I find information that contradicts } \\
\text { itself (3) }\end{array}$ & & & & & \\
\hline $\begin{array}{l}\text { I don't trust the information I find } \\
\text { (4) }\end{array}$ & & & & & \\
\hline $\begin{array}{l}\text { I would rather ask someone for } \\
\text { help than look for information on } \\
\text { my own (5) }\end{array}$ & & & & & \\
\hline
\end{tabular}

Q9 Financial literacy is a broad term that includes knowledge about personal finance, budgets, savings, spending, etc. Have you had any formal financial literacy instruction of this nature?

$\square \quad$ Yes (1)

$\square \quad$ No (2)

$\square$ Other (3)

Q10 What is your age?

$\square \quad 18-20(1)$

$\square \quad 21-23(2)$

$\square \quad 24-26(3)$

$\square \quad 27-29(4)$

$\square \quad 30$ or older (5) 
Q11 What is your class standing?

$\square \quad$ Freshman (1)

$\square \quad$ Sophomore (2)

$\square$ Junior (3)

$\square$ Senior (4)

$\square \quad$ Graduate (5)

$\square$ Other (6)

Q12 What gender identity do you most identify with?

$\square \quad$ Female (1)

$\square \quad$ Male (2)

$\square \quad$ Prefer not to say (3)

$\square \quad$ Prefer to self-describe (4)

Q13 How do you describe your ethnicity?

White (1)

Hispanic or Latino (2)

Black or African American (3)

$\square \quad$ Native American or American Indian (4)

$\square \quad$ Asian/Pacific Islander (5)

$\square$ Other (6)

Prefer not to answer (7)

Q14 Are you a first generation student?

$\square$ Yes (1)

$\square \quad$ No (2)

\section{Notes}

1. Kit Keller et al., "Meeting the Need for Library-Based Financial Literacy Education," Reference \& User Services Quarterly 54, no. 3 (2015): 47-51.

2. Keller et al., "Meeting the Need for Library-Based Financial Literacy Education."

3. Catherine Arnott Smith and Kristin Eschenfelder, "Public Libraries in an Age of Financial Complexity: Toward Enhancing Community Financial Literacy," Library Quarterly 83, no. 4 (October 2013): 299-320.

4. Trevor A. Dawes, "Libraries, ACRL and Financial Literacy: Helping Students Make Sound Decisions," College \& Research Libraries News 74, no. 9 (October 2013): 466-67; Heather Jagman et al., "Financial Literacy across the Curriculum (and Beyond)," College E Research Libraries News 75, no. 5 (May 2014): 254-57; John Roggenkamp, "Financial Literacy and Community Colleges," College \& Research Libraries News 75, no. 3 (March 2014): 142-43; Esther L. Gil, "Leading the Way for Financial Literacy Education: A Case Study on Collaboration," Journal of Business E Finance Librarianship 20, no. 1/2 (April 3, 2015): 27-53, https://doi.org/10.1080/08963568.2015.978710; Lauren Reiter, "Financial Literacy and the Academic Library: Exploring the Peer-to-Peer Approach," Journal of Business $\mathcal{E}$ Finance Librarianship 20, no. 1/2 (April 3, 2015): 54-65, https://doi.org/10.1080/08963568.2015.977732; Wendy C. Doucette, "Why Our Financial Literacy Programming Died (and How Yours Can Succeed)," Tennessee Libraries 67, no. 4 (2017); Tammy Woodward and Sarah Timm, "Creating Money Smart Students: Using Money Smart Week as a Platform for Outreach in an Academic Library," Texas Library Journal 91, no. 4 (2015): 9-10; Emily Mross and Lauren Reiter, "Partners in Financial Literacy: Outreach to Student Entrepreneurs," College E Research Libraries News 80, no. 10 (November 2019): 575; Emily Mross, “Laughing All the Way to the Bank Using Television Clips to Promote Financial Literacy," Ticker: The Academic Business Library Review 4, no. 1 (2019); Alyson Vaaler and Jennifer Wilhelm, "Teaching Financial Literacy through the Use of Market Research and Advertising Instruc- 
tion: A Non Traditional Approach," Reference Services Review 48, no. 2 (2020): 258-70.

5. Lauren Reiter and Bronson Ford, "Library Support for Student Financial Literacy: A Survey of Librarians at Large Academic Institutions," College E Research Libraries 80, no. 5 (July 2019): 618-37.

6. Ashley E. Faulkner, "Financial Literacy Education in the United States: Exploring Popular Personal Finance Literature," Journal of Librarianship and Information Science 49, no. 3 (November 20, 2015): 287-98, https:// doi.org/10.1177/0961000615616106.

7. Ashley E. Faulkner, "Financial Literacy Education in the United States: Library Programming versus Popular Personal Finance Literature," Reference \& User Services Quarterly 56, no. 2 (2016): 116-25.

8. Smith and Eschenfelder, "Public Libraries in an Age of Financial Complexity"; Keller et al., "Meeting the Need for Library-Based Financial Literacy Education"; Reiter and Ford, "Library Support for Student Financial Literacy."

9. Smith and Eschenfelder, "Public Libraries in an Age of Financial Complexity"; Faulkner, "Financial Literacy Education in the United States"; Reiter and Ford, "Library Support for Student Financial Literacy."

10. Lynn Sillipigni Connaway, Timothy J. Dickey, and Marie L. Radford, "If It Is Too Inconvenient I'm Not Going after It: Convenience as a Critical Factor in Information-Seeking Behaviors," Library \& Information Science Research 33, no. 3 (Jul. 2011): 179-90, https://doi.org/10.1016/j.lisr.2010.12.002.

11. Sloan Komissarov and James Murray, "Factors that Influence Undergraduate Information-seeking Behavior and Opportunities for Student Success," Journal of Academic Librarianship 42, no. 4 (Jul. 2016): 423-29, https://doi. org/10.1016/j.acalib.2016.04.007.

12. Barbara Blummer, Sara Lohnes Watulak, and Jeffrey Kenton, "The Research Experience for Education Graduate Students: A Phenomenographic Study," Internet Reference Services Quarterly 17, no. 3/4 (Jul.-Dec. 2012): 117-46, https://doi.org/10.1080/10875301.2012.747462;

Julie Carpenter et al., Researchers of Tomorrow: The Research Behavior of Generation Y Doctoral Students (London, UK: British Library and JISC, 2007), https://www.jisc.ac.uk/reports/researchers-of-tomorrow; Andrea B. TwissBrooks et al., "A Day in the Life of Third-Year Medical Students: Using an Ethnographic Method to Understanding Information Seeking and Use," Journal of Medical Library Association 105, no. 1 (Jan. 2017): 12-19, https://doi. org/10.5195/jmla.2017.95.

13. Reijo Savolainen, "Everyday Life Information Seeking: Approaching Information Seeking in the Context of Way of Life," Library \& Information Science Research 17, no. 3 (1995): 259-94, https://doi.org/10.1016/07408188(95)90048-9; Elizabeth Yakel, "Seeking Information, Seeking Connections, Seeking Meaning: Genealogists and Family Historians," Information Research 10, no. 1 (Oct. 2004), http://informationr.net/ir/10-1/paper205.html.

14. Ann Starasts, "Unearthing Farmer's Information Seeking Contexts and Challenges in Digital, Local and Industry Environments," Library E Information Science Research 37, no. 2 (Apr. 2015): 156-63, https://doi.org/10.1016/j. lisr.2015.02.004; Carol Tenopir and Donald W. King, Communication Patterns of Engineers (Piscataway, NJ: IEEE Press, 2004); Anne M. Turner et al., "From the Ground Up: Information Needs of Nurses in a Rural Public Health Department in Oregon," Journal of the Medical Library Association 96, no. 4 (Oct. 2008): 335-42, https://doi. org/10.3163/1536-5050.96.4.008; Christopher P. Lueg, “Beyond FAQs: From Information Sharing to Knowledge Generation in Online Travel Communities," in Proceedings of the International Conference for the Celebration of the 20th Anniversary of Information Studies, eds. Maija-Leena Huotari and Elisabeth Davenport (Oulu, Finland: Oulu University Press, 2008), 105-20; Jameson Otto, Sara Metz, and Nathan Ensmenger, "Sports Fans and Their Information Gathering Habits: How Media Technologies Have Brought Fans Closer to Their Teams over Time," in Everyday Information: The Evolution of Information Seeking in America, eds. William Aspray and Barbara M. Hayes (Cambridge, MA: MIT Press, 2011), 185-216.

15. Kathrin Johansen, "Information Search in Pension Plan Decisions," Applied Economics Letters 20, no. 18 (Dec. 2013): 1648-50, https://doi.org/10.1080/13504851.2013.831163.

16. Chungwen Hsu, "Information Sources and Retirement Savings of Working Women," Journal of Financial Counseling and Planning 27, no. 2 (Dec. 2016): 252-64, http://dx.doi.org/10.1891/1052-3073.27.2.252.

17. Lisa G. O'Connor, "Investors' Information Sharing and Use in Virtual Communities," Journal of the American Society for Information Science \& Technology 64, no. 1 (Dec. 2012): 36-47, https://doi.org/10.1002/asi.22791.

18. Lu Fan and Swarn Chatterjee, "Borrowing Decisions of Households: An Examination of the Information Search Process," Journal of Financial Counseling and Planning 28, no. 1 (June 2017): 95-106, https://doi.org/10.1891/10523073.28.1.95.

19. Reijo Savolainen, "Source Preference Criteria in the Context of Everyday Projects: Relevance Judgements Made by Prospective Home Buyers," Journal of Documentation 66, no.1 (Jan. 2010): 70-92, https://doi. org/10.1108/00220411011016371.

20. Lan Xia, "An Examination of Consumer Browsing Behaviors," Qualitative Market Research 13, no. 2 (Apr. 2010): 154-73, https://doi.org/10.1108/13522751011032593. 
21. Haiyang Chen and Ronald P. Volpe, "An Analysis of Personal Financial Literacy among College Students," Financial Services Review 7, no. 2 (1998): 107-28; Michael E. Hanna, Robert R. Hill, and Grady Perdue, "School of Study and Financial Literacy," Journal of Economics and Economic Education Research 11, no. 3 (September 2010); Lewis Mandell and Linda Schmid Klein, "The Impact of Financial Literacy Education on Subsequent Financial Behavior," Journal of Financial Counseling and Planning 20, no. 1 (2009): 15-24.

22. Annamaria Lusardi and Dorothy Wallace, "Financial Literacy and Quantitative Reasoning in the High School and College Classroom," Numeracy 6, no. 2 (2013): 1-5, http://dx.doi.org/10.5038/1936-4660.6.2.1.

23. Andrew C. Worthington, "Predicting Financial Literacy in Australia," Financial Services Review 15, no. 1 (Spring 2006): 59-79; Paul Gerrans, Richard Heaney, and Tom Smith, "The Impact of Undergraduate Personal Finance Education on Individual Financial Literacy, Attitudes and Intentions," Accounting \& Finance 59, no. 1 (2019): 177-217, https://doi.org/10.1111/acfi.12247; Abdullah Al-Bahrani, Jamie Weathers, and Darshak Patel, "Racial Differences in the Returns to Financial Literacy Education," Journal of Consumer Affairs 53, no. 2 (Summer 2019): 572-99, https://doi.org/10.1111/joca.12205.

24. Chen and Volpe, "An Analysis of Personal Financial Literacy among College Students"; Pamela M. LaBorde, Sandra Mottner, and Pamela Whalley, "Personal Financial Literacy: Perceptions of Knowledge, Actual Knowledge and Behavior of College Students," Journal of Financial Education 39, no. 3/4 (Fall/Winter 2013): 1-30; Al-Bahrani, Weathers, and Patel, "Racial Differences in the Returns to Financial Literacy Education"; Angela J. Murphy, "Money, Money, Money: An Exploratory Study on the Financial Literacy of Black College Students," College Student Journal 39, no. 3 (2005): 478-88.

25. Chen and Volpe, "An Analysis of Personal Financial Literacy among College Students"; Murphy, "Money, Money, Money"; Hanna, Hill, and Perdue, "School of Study and Financial Literacy."

26. Chen and Volpe, "An Analysis of Personal Financial Literacy Among College Students."

27. Murphy, "Money, Money, Money"; Jing Jian Xiao et al., "Earlier Financial Literacy and Later Financial Behaviour of College Students," International Journal of Consumer Studies 38, no. 6 (2014): 593-601, https://doi. org/10.1111/ijcs.12122; Gerrans, Heaney, and Smith, "The Impact of Undergraduate Personal Finance Education on Individual Financial Literacy, Attitudes and Intentions."

28. Murphy, "Money, Money, Money"; Hanna, Hill, and Perdue, "School of Study and Financial Literacy."

29. LaBorde, Mottner, and Whalley, "Personal Financial Literacy."

30. Alison J. Head and Michael B. Eisenberg, "How College Students Use the Web to Conduct Everyday Life Research," First Monday 16, no. 4 (2011), https://firstmonday.org/ojs/index.php/fm/article/download/3484/2857.

31. Emily J. Huang, Reka A. Lassu, and Kenny K. Chan, "User-Source Fit and Financial Information Source Selection of Millennials," Journal of Financial Counseling and Planning 29, no. 2 (2018): 272-89, https://doi. org/10.1891/1052-3073.29.2.272.

32. The Ohio State University Office of Student Life, "Study on Collegiate Financial Wellness: 2017 Key Findings Report" (2017), https://cssl.osu.edu/posts/632320bc-704d-4eef-8bcb-87c83019f2e9/documents/2017-scfw-keyfindings-report.pdf.

33. Lauren E. Willis, "Against Financial-Literacy Education," Iowa Law Review 94, no. 1 (2008): 197-285.

34. Mandell and Klein, "The Impact of Financial Literacy Education on Subsequent Financial Behavior."

35. Gerrans, Heaney, and Smith, "The Impact of Undergraduate Personal Finance Education on Individual Financial Literacy, Attitudes and Intentions"; Jamie Wagner and William B. Walstad, "The Effects of Financial Education on Short-Term and Long-Term Financial Behaviors," Journal of Consumer Affairs 53, no. 1 (2019): 234-59, https://doi.org/10.1111/joca.12210.

36. Daniel Fernandes, John G. Lynch, and Richard G. Netemeyer, "Financial Literacy, Financial Education, and Downstream Financial Behaviors," Management Science 60, no. 8 (2014): 1861-2109, https://doi.org/10.1287/ mnsc.2013.1849.

37. Margaret Miller et al., "Can You Help Someone Become Financially Capable? A Meta-Analysis of the Literature," Policy Research Working Paper 6745: Background Paper to the 2014 Global Financial Development Report (January 2014): 3, http://documents.worldbank.org/curated/en/297931468327387954/pdf/WPS6745.pdf.

38. "Student Demographics," Texas A\&M University Accountability, Fall 2019, https://accountability.tamu. edu/All-Metrics/Mixed-Metrics/Student-Demographics.

39. Connaway, Dickey, and Radford, "If It Is Too Inconvenient I'm Not Going after It"; Komissarov and Murray, "Factors That Influence Undergraduate Information-seeking Behavior and Opportunities for Student Success." 40. Reiter and Ford, "Library Support for Student Financial Literacy."

41. Reiter and Ford, "Library Support for Student Financial Literacy."

42. Tyler Mondres, "How Generation Z Is Changing Financial Services: Move Over, Millennials. The Next Rising Generation Is Here," ABA Banking Journal 111, no. 1 (Jan/Feb 2019): 24-28; Nikolaos D. Philippas and Christos Avdoulas, "Financial Literacy and Financial Well-Being Among Generation-Z University Students: Evidence from Greece," European Journal of Finance 26, no. 4/5 (2020): 360-81. 